\title{
Comparative leaf anatomical studies reveal photosynthetic pathways type in guinea grass (Panicum maximum Jacq.) accessions and their interspecific lineage
}

\author{
Devendra Ram Malaviya ${ }^{1,2, *}$, Ajoy Kumar $\operatorname{Roy}^{1}$ and Pankaj Kaushal ${ }^{1,3}$ \\ ${ }^{1}$ ICAR-Indian Grassland and Fodder Research Institute, Jhansi 284003 India \\ ${ }^{2}$ Present address: ICAR-Indian Institute of Sugarcane Research, Lucknow 206 002, India \\ ${ }^{3}$ Present address: ICAR-National Institute of Biotic Stress Management, Baronda, Raipur 493 225, India
}

Kranz anatomy studied among Panicum maximum accessions showed wide variation for chloroplast in bundle sheath (BS), mesophyll and mestome. Genotypes in clusters $\mathrm{E}$ and $\mathrm{F}$, with $<20 \%$ pigmentation in BS, had lineage with $P$. prionitis, $P$. rivulare, $P$. laxum, $P$. hylacicum and $P$. bisulcatum, whereas genotypes in clusters $B, C$ and $D$ with high pigmentation were $C_{4}$ types having lineage with $P$. antidotale, $P$. coloratum and $P$. miliaceum. Genotypes with $\sim 50 \%$ pigmentation in cluster $A$ were intermediate types and might have evolved either through intraspecies crossing or species like $P$. milioides, $P$. decipens, $P$. schenckii and $P$. petersoni.

Keywords: $\mathrm{C}_{3}-\mathrm{C}_{4}$ photosynthesis, germplasm, guinea grass, interspecific lineage, leaf anatomy.

GLOBALLY, $79 \%$ of all $\mathrm{C}_{4}$ plants belong to monocots and only $21 \%$ belong to dicots ${ }^{1}$. Among these $\mathrm{C}_{4}$ species, which include many tropical grasses are adapted to warmer climate and produce high biomass. Panicum, a cosmopolitan genus, is a heterogeneous assemblage of approximately 500 species $^{2}$. In the West African savannah, Panicum spp. and closely related taxa dominate the landscape, with species differentially adapted to drought conditions $^{3}$. The genus is reported to have species with different photosynthetic pathways. $\mathrm{C}_{4}$ grasses are the most common species in the prairies ecosystem of North America, vast grasslands of Africa, and the Llanos and Cerrados of South America which developed 5-6 million years $\mathrm{ago}^{4}$. It was postulated in a study based on anatomical and physiological data, that a $\mathrm{C}_{3}$ Panicum could be the ancestor of all remaining Paniceae, and the genus has both $\mathrm{C}_{3}$ and $\mathrm{C}_{4}$ photosynthetic systems ${ }^{5}$ and also some $\mathrm{C}_{3} / \mathrm{C}_{4}$ intermediate species ${ }^{6-11}$. The $\mathrm{C}_{4}$ Panicum species also include representatives of the PEP-CK, NAD-ME and NADP-ME subtypes ${ }^{12,13}$.

Among various Panicum species, $P$. maximum (guinea grass) is a widely adapted perennial grass for utilization

*For correspondence. (e-mail: drmalaviya47@ rediffmail.com) as fodder because of its ease of propagation, fast regrowth and high nutritional quality. During rainy season, it can yield 40-60 tonne/ha dry matter with crude protein content up to $14 \%$ and $41-72 \%$ dry matter digestibility ${ }^{14,15}$. Availability of annual as well as perennial types makes the crop suitable for irrigated as well as rainfed conditions $(400-1500 \mathrm{~mm} / \text { year rainfall })^{16}$. Evaluation of global germplasm collection of guinea grass, at the Indian Grassland and Fodder Research Institute (ICAR-IGFRI), Jhansi, India showed high degree of variation for several traits, including biomass yield ${ }^{16-20}$. In the context of such a high genotypic variation for morphology, adaptation and biomass yield, it becomes imperative to have an insight into the variation of photosynthetic pathways; this also reflects the evolutionary linkage of the species based on diversity for Kranz anatomy. Hence, the present work was undertaken to anatomically screen the global germplasm collection of $P$. maximum to examine the evolutionary significance of diversity for photosynthetic pathways.

\section{Material and methods}

One hundred and sixty-three germplasm accessions of $P$. maximum, being maintained at the Gene Bank (midterm storage module) of IGFRI, Jhansi, were used in the present study (Supplementary Table 1). The plants were raised in paired rows of $3 \mathrm{~m}$ each accommodating six tussocks in each row $60 \mathrm{~cm}$ apart in July 2010 at the experimental farm of the Institute. Standard cultural practice was followed for raising the crops. Young and fully expanded leaves were collected from 30-day-old crops after first cut at 45 days. Fine sections leaves were cut by placing a small piece of the leaf in a pith and cutting using common razor/blade and immersing in distilled water to keep them moist. Five leaves were taken from each germplasm accession and the single best section of each leaf was taken for observation under a compound light microscope (Nikon), and taken on an unstained section following earlier workers ${ }^{21}$; however, the sections 
were not subjected to softening because the anatomy in thin sections was quite clear and chloroplast was seen distinctly.

Chloroplast pigmentation was observed in mestome cells, outer bundle sheath cells (BSCs) and mesophyll cells (MCs) close to the mid vascular bundle (MVB) and one side vascular bundle (SVB) next to MVB. The number of cells making the bundle sheath was also counted. The area occupied by the chloroplast in a cell was recorded on the basis of visual estimation under a microscope. Observations were recorded on five cells in each sample and average was considered for further analysis. Distribution of chloroplast in the cells was categorized as centrifugal, centripetal and scattered. Shape of the mesophyll cells was recorded as rhomboid, elliptical and palisade.

Stomata were observed for their shape, i.e. sunken, elevated and levelled. Additionally, bulbiform motor cells were also observed on the adaxial surface of the leaves. The stomata present below the epidermal layer were recorded as 'sunken', whereas those on the same level as 'levelled' and the ones extended above the surface as 'elevated'. The number of cells per bulbiform was also counted as one middle cell accompanied with one or two cells on either side.

Standard deviation and mean were calculated using Microsoft Excel program. The metric traits data were analysed statistically using Non-Hierarchical Euclidean

Table 1. Variability for leaf anatomy among genotypes of Panicum maximum

\begin{tabular}{|c|c|c|}
\hline Character & Variation & $\begin{array}{l}\text { Number of } \\
\text { genotypes }\end{array}$ \\
\hline Mestome & $\begin{array}{l}\text { Well defined } \\
\text { Poorly defined } \\
\text { Absent }\end{array}$ & $\begin{array}{r}150 \\
2 \\
11\end{array}$ \\
\hline Chloroplast in mestome & $\begin{array}{l}\text { Centripetal } \\
\text { Absent } \\
\text { Scattered }\end{array}$ & $\begin{array}{r}131 \\
29 \\
3\end{array}$ \\
\hline Mesophyl cell shape & $\begin{array}{l}\text { Rhomboid } \\
\text { Elliptical } \\
\text { Palisade }\end{array}$ & $\begin{array}{l}99 \\
43 \\
21\end{array}$ \\
\hline $\begin{array}{l}\text { Distance between Mid } \\
\text { Vascular Bundle (MSV) and } \\
\text { side vascular bundle } \\
\text { (SVB); no. of cells }\end{array}$ & $\begin{array}{l}\text { One } \\
\text { Two } \\
\text { One to two }\end{array}$ & $\begin{array}{l}41 \\
38 \\
84\end{array}$ \\
\hline $\begin{array}{l}\text { Chloroplast in outer bundle } \\
\text { sheath }\end{array}$ & $\begin{array}{l}\text { Centrifugal } \\
\text { Centripetal } \\
\text { Scattered }\end{array}$ & $\begin{array}{r}109 \\
3 \\
51\end{array}$ \\
\hline Stomata shape & $\begin{array}{l}\text { Sunken } \\
\text { Levelled } \\
\text { Elevated }\end{array}$ & $\begin{array}{l}90 \\
63 \\
10\end{array}$ \\
\hline Number of stomatal cells & $\begin{array}{l}\text { Three } \\
\text { Five } \\
\text { Three and five }\end{array}$ & $\begin{array}{r}115 \\
8 \\
40\end{array}$ \\
\hline
\end{tabular}

Cluster Analysis for grouping of genotypes ${ }^{22}$. Analysis was done using NTSYSpc version 2.02e software ${ }^{23}$. The similarity/dissimilarity matrix coeff EUCLID of SIMINT module was used to work out dissimilarity. The module NJOIN was used to generate the dendrogram.

\section{Results}

\section{Vein density}

The vascular system in leaves is composed of large and small longitudinal veins, and transverse veins. Leaf anatomy study among 163 genotypes of $P$. maximum revealed one to two cells distance between longitudinal veins, i.e. MVB and SVB in majority of cases. A good number of genotypes (48) showed single-cell distance (Table 1). The distance between other SVBs was also one to two cells in majority of cases (Figure 1). A large number of parallel small veins with one to two cells distance between veins along with a single large vein were present in the thin leaves.

\section{Bundle sheath}

The genotypes showed two layers of bundle sheath with centripetal chloroplast pigmentation in mestome sheath and centrifugal or scattered in the outer bundle sheath in majority of cases. Mestome cells in MVB were well defined in majority of the genotypes, except in 11 genotypes wherein mestome was absent and in two they were poorly defined (Table 1). On an average, 10 large parenchymatous BSCs surrounded MVB, whereas SVBs were surrounded by an average 4.4 such cells. Majority of the cells surrounding MVBs in all the accessions were seen with chloroplast pigmentation, except in six accessions wherein $<70 \%$ cells were seen with chloroplast pigmentation (Table 2 and Figure 1). The cells surrounding SVBs mostly showed the presence of chloroplasts among all accessions. However, the per cent area covered with chloroplasts was highly variable. The BSCs cells of MVB on an average showed $69.3 \%$ area occupied by chloroplasts, although variation was observed from $3 \%$ to $100 \%$ (Table 2 ). Five genotypes showed $<10 \%$ area occupied by chloroplasts in less than $50 \%$ BSCs (Table 2). A similar trend was also observed with BSCs of SVB. The outer BSCs were quite large in size and filled with organelles, mainly chloroplasts. The area covered by such BSCs was much higher compared to their proportionate number. Some genotypes (11) were found to have only one sheath and the outer BSCs packed with centrifugal chloroplasts. Fifty-one genotypes had outer BSCs with few scattered/ granal chloroplasts. Three genotypes showed the presence of scattered chloroplasts in the inner BSCs instead of the centripetal arrangement among majority (131). In the present study, the inner bundle sheath was not distinct among 13 genotypes. 


\section{RESEARCH ARTICLES}

Table 2. Chloroplast pigmentation in bundle sheath cells in accessions of $P$. maximum leaves

\begin{tabular}{|c|c|c|c|c|c|c|c|c|}
\hline & \multicolumn{4}{|c|}{ Mid Vascular Bundle } & \multicolumn{4}{|c|}{ Side Vascular Bundle } \\
\hline & \multirow{2}{*}{$\begin{array}{l}\text { No. of } \\
\text { cells }\end{array}$} & \multirow{2}{*}{$\begin{array}{l}\text { Cells with } \\
\text { chloroplast }\end{array}$} & \multicolumn{2}{|c|}{$\begin{array}{c}\text { Area with } \\
\text { chloroplast }(\%)\end{array}$} & \multirow{2}{*}{$\begin{array}{l}\text { No. of } \\
\text { cells }\end{array}$} & \multirow{2}{*}{$\begin{array}{l}\text { Cells with } \\
\text { chloroplast }\end{array}$} & \multicolumn{2}{|c|}{$\begin{array}{c}\text { Area with } \\
\text { Chloroplast }(\%)\end{array}$} \\
\hline & & & BSC & $\mathrm{MC}$ & & & BSC & $\mathrm{MC}$ \\
\hline Average & 10.0 & 9.2 & 69.3 & 52.1 & 4.4 & 4.2 & 65.8 & 49.3 \\
\hline Minimum & 7.2 & 5.0 & 3.0 & 4.2 & 4.0 & 2.8 & 3.2 & 13.8 \\
\hline Maximum & 13.4 & 12.8 & 100.0 & 91.0 & 6.0 & 6.0 & 100.0 & 84.0 \\
\hline SD & 1.09 & 1.44 & 26.07 & 15.13 & 0.35 & 0.40 & 23.59 & 14.91 \\
\hline
\end{tabular}

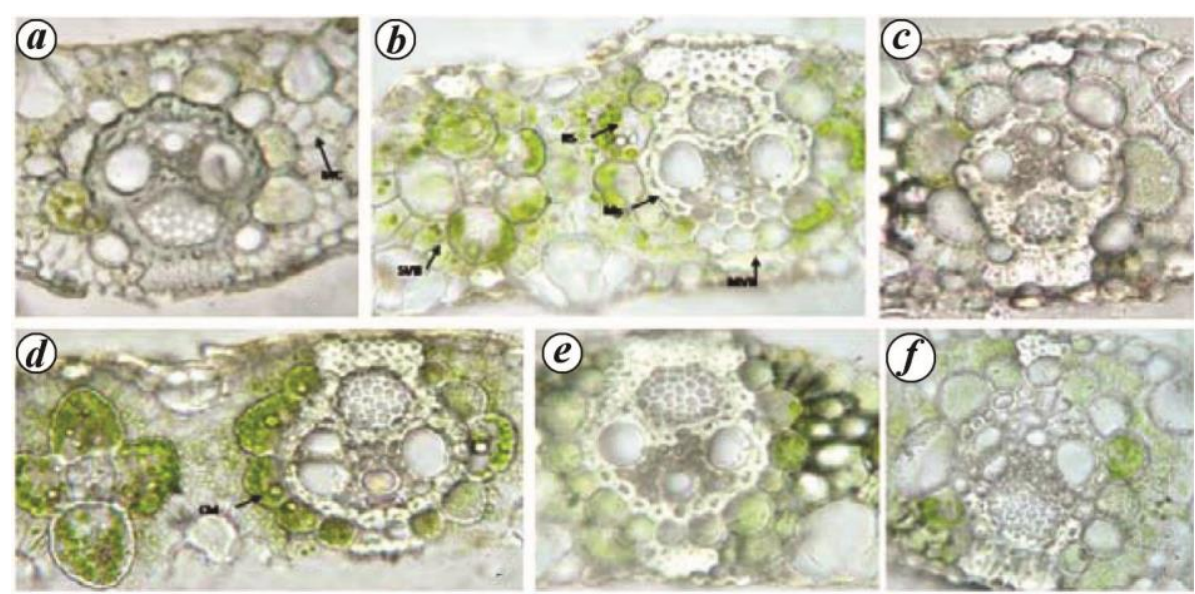

(8)

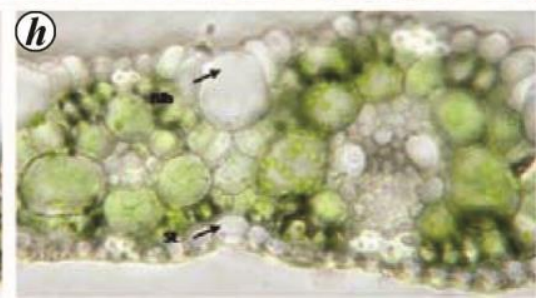

Figure 1. Photomicrographs of transverse section of different accessions of Panicum maximum showing variation of pigmentation in bundle sheath cells (BSCs). $\boldsymbol{a}$, Accession IG 01-108 with double bundle sheath and round mesophyll cells. $\boldsymbol{b}$, Accession PC 313 with double sheath and centrifugal chloroplast in BSCs of mid-vascular bundle (MVB) and side vascular bundle (SVB). $\boldsymbol{c}$, Accession IG 01-87 with poor pigmentation in BSCs. $\boldsymbol{d}$, Accession IG 01-124 with well-defined mestome and centrifugal chloroplast in BSCs. $\boldsymbol{e}$, Accession IG 97-36 with centripetal chloroplast in mestome. $\boldsymbol{f}$, Accession IG 01-151 with discontinuous mestome. $\boldsymbol{g}$, Accession N03-427 showing close small veins. $\boldsymbol{h}$, Accession N03-427 with scattered chloroplast in BSCs.

Correlation analysis for chlorophyll pigmentation showed positive correlation between per cent area occupied by chlorophyll in BSCs and that in MCs of both MVBs (0.5381) and SVBs (0.6002), indicating that increased pigmentation in BSCs was also associated with pigmentation in MCs. Similarly, pigmentation in BSCs of MVBs and SVBs was also positively correlated (0.8012) with similar trend for positive correlation in $\mathrm{MCs}$ (0.6660). Positive correlation (0.5787) was also observed between per cent BSCs with pigmentation and per cent area in pigmentation in BSCs.

\section{Mesophyll cells}

The mesophyll cells around MVS showed a range from $4.2 \%$ to $91 \%$ (mean $52.1 \%$ ) of area occupied by green pigment (Table 2). Palisade-shaped mesophyll cells are common among $\mathrm{C}_{4}$ anatomy; however, in the present study, only 21 genotypes showed the presence of such cells, whereas majority (99 genotypes) had rhomboid cells and 43 had elliptical cells (Table 2). The number of inner and outer BSCs (data not presented) was either more or equal to the number of MCs. The intercellular space among MCs was also minimum.

\section{Stomata and bulbiform cells}

All the genotypes showed regular presence of one sunken stomata on the abaxial surface and one set of bulbiform motor cells on the abaxial leaf surface between two veins. The number and the position of bulbiform cells with 
RESEARCH ARTICLES

Table 3. Average of different anatomical traits of each cluster in P. maximum

\begin{tabular}{|c|c|c|c|c|c|c|c|c|c|c|}
\hline \multirow[b]{3}{*}{ Group } & & & \multicolumn{4}{|c|}{ MVB } & \multicolumn{4}{|c|}{ SVB } \\
\hline & \multicolumn{2}{|c|}{ No. genotypes } & \multirow[b]{2}{*}{ No. of BSC } & \multirow{2}{*}{$\begin{array}{l}\text { BSC with } \\
\text { chloroplast }\end{array}$} & \multicolumn{2}{|c|}{$\begin{array}{c}\text { Area with } \\
\text { chloroplast }(\%)\end{array}$} & \multirow[b]{2}{*}{ No. of BSC } & \multirow{2}{*}{$\begin{array}{l}\text { BSC with } \\
\text { chloroplast }\end{array}$} & \multicolumn{2}{|c|}{$\begin{array}{c}\text { Area with } \\
\text { chloroplast }(\%)\end{array}$} \\
\hline & Indigenous & Exotic & & & BSC & $\mathrm{MC}$ & & & BSC & MC \\
\hline Cluster A & 7 & 1 & 9.7 & 8.3 & 43.3 & 37.7 & 4.6 & 4.4 & 43.2 & 25.6 \\
\hline Cluster B & 23 & 0 & 10.7 & 10.3 & 88.3 & 51.3 & 4.4 & 4.2 & 84.5 & 49.4 \\
\hline Cluster C & 45 & 7 & 10.1 & 9.7 & 82.7 & 58.5 & 4.4 & 4.3 & 84.8 & 61.1 \\
\hline Cluster D & 39 & 19 & 9.8 & 9.0 & 71.7 & 53.0 & 4.4 & 4.2 & 58.6 & 44.9 \\
\hline Cluster E & 13 & 3 & 9.5 & 7.9 & 21.3 & 40.5 & 4.5 & 4.0 & 36.5 & 45.0 \\
\hline Cluster F & 5 & 1 & 10.6 & 7.5 & 9.6 & 36.8 & 4.9 & 3.9 & 8.1 & 35.3 \\
\hline
\end{tabular}

respect to the epidermal cells differed. Among majority of the genotypes (90), it was sunken, quite a good number of genotypes (63) showed at the epidermal cell layer level, whereas among 10 genotypes it was elevated (Table 2). The bulbiform cells were mostly three in number, whereas in 40 genotypes it varied from 3 to 5 cells. Only eight genotypes showed five bulbiform cells per stomatal apparatus.

\section{Clustering of genotypes}

In the Non-Hierarchical Euclidean Cluster Analysis for the grouping of genotypes, six well-separated clusters were formed (Figure 2). Very high number of genotypes was observed in clusters $\mathrm{C}$ and $\mathrm{D}$ (52 and 58 respectively) (Table 3). Genotypes in clusters $\mathrm{F}$ and $\mathrm{A}$ were minimum (6 and 8 respectively). Genotypes with high number of cells having chloroplasts in BSCs of MVB, clustered in groups B, C and D. Per cent area occupied by chloroplasts in BSCs of MVB was minimum in cluster F (9.6), followed by 21.3 in cluster E and 43.3 in cluster A. Similar trend was observed for chloroplast pigments in BSCs of SVB. Most of the exotic genotypes from Ethiopia clustered in cluster D (19 nos), followed by 7 in cluster C. Sporadic presence of a few exotic genotypes was noted in all the remaining clusters, except cluster B.

\section{Discussion}

Guinea grass exhibits a high degree of variation for several traits, including biomass yield and adaptation to growing conditions ${ }^{16-20,24}$. The residual sexuality coupled with various modes of recombination in apomictic seed formation has contributed to tremendous intra-species morphological variations ${ }^{25,26}$. The present study highlights the extent of intra-species diversity for photosynthetic pathway in $P$. maximum and its evolutionary significance.

The $\mathrm{C}_{4}$ photosynthetic pathway is considered to have evolved from $\mathrm{C}_{3}$ and is more efficient in $\mathrm{CO}_{2}$ fixation.
Such plants have higher photosynthetic rates under high irradiance and at high temperatures than $C_{3}$ plants ${ }^{27}$. Plants with $\mathrm{C}_{4}$ photosynthesis are grouped into three subtypes differing in the process of decarboxylation of $\mathrm{C}_{4}$ acids: the NADP-malic enzyme (NADP-ME), NADmalic enzyme (NAD-ME) and phosphoenolpyruvate carboxykinase (PCK) types ${ }^{28}$. Bundle sheath cells and pigmentation therein; mesophyll cell shape, size and pigmentation; vein density and presence of mestome and pigmentation therein contribute to the mode of photosynthetic pathway.

Panicum was considered as homogeneously $\mathrm{C}_{4}$ (NADME subtype) subgenus ${ }^{5}$. However, later some species (e.g. P. elephantipes) were described as PEP-CK type ${ }^{29}$; $P$. milioides to be intermediate type $\mathrm{C}_{3}-\mathrm{C}_{4}$ (ref. 30); $P$. antidotale to be NADP-ME; P. coloratum L. var. Makarikariense, $P$. dichotomiflorum Michaux and $P$. miliaceum L. to be NAD-ME. $P$. maximum was reported to be $\mathrm{C}_{4}$, of the PEP-CK photosynthetic subtype ${ }^{31-33}$.

Enhanced photosynthetic rates require a quick transport mechanism with denser vascular system $^{33}$ and larger cross-sectional area of phloem. Majority of genotypes showed high vein density and the distance between longitudinal veins was one to two cells along with very close distance from BSCs to stomatal cells, thus facilitating better photosynthetic efficiency. Minimum interveinal distance was reported in NADP-ME $\mathrm{C}_{4}$ subtype $^{34}$, although no difference among subtypes was reported ${ }^{33}$. Accordingly, most of the genotypes in the present study belonged to NADP-ME.

The Kranz species of subgenus Panicum are described to have mestome and outer parenchymatous sheath with centripetal chloroplasts ${ }^{31}$. However, high vein density has been linked to its origin from mestome and such plants are characterized as NADP-ME type ${ }^{32,35}$. Kranz cells in NADP-ME and PEP-CK possess centrifugal chloroplasts whereas it is centripetal in NAD-ME. In the present study, a majority of genotypes possessed two layers of bundle sheath in MVB with centripetal chloroplast pigment in mestome and centrifugal or scattered in outer bundle sheath. However, the SVBs had single 


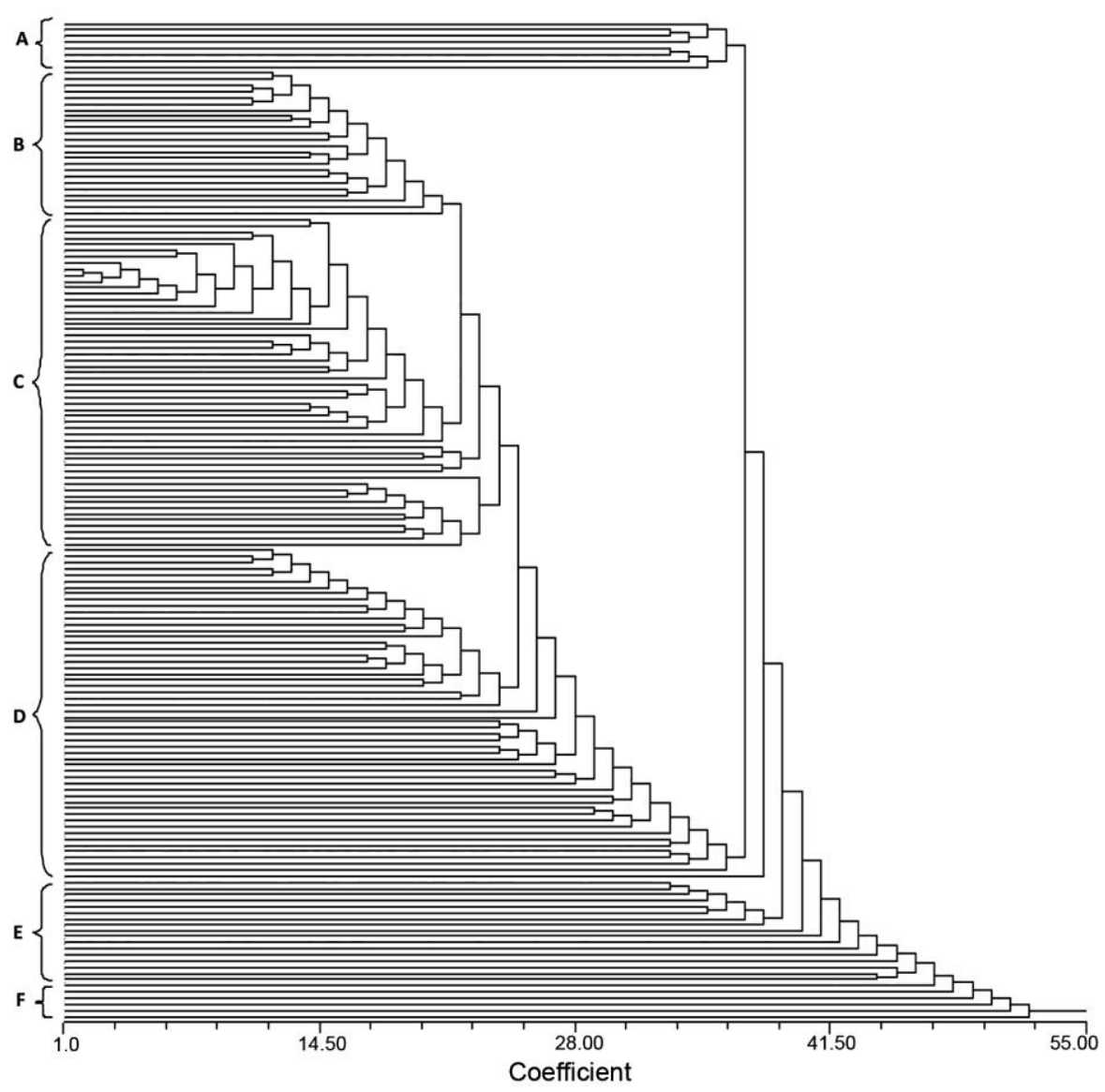

Figure 2. Dendrogram showing Euclidean clustering of genotypes.

parenchymatous bundle sheath. A few genotypes lacking mestome sheath thus belonged to NADP-ME sub-type. Among majority of genotypes, the origin of BSCs appeared to be from parenchyma sheath cells placing those genotypes in either of the two types, i.e. NAD-ME or PCK. Thus, these variations suggest that there are genotypes belonging to different subtypes of $\mathrm{C}_{4}$ and accession represents mixed traits as defined by different workers for different subtypes. Also, it is possible that in spite of the presence of mestome sheath, the genotypes belonged to NADP-ME type.

The number of BSCs surrounding MVBs as well as SVBs and pigmentation therein is the most important feature for $\mathrm{C}_{4}$ photosynthesis. Significant differences among genotypes were observed for the number of BSCs surrounding $\mathrm{MVBs}$ and pigmentation therein, whereas among SVBs, almost uniform presence of chloroplasts in BSCs was observed. Variation in pigmentation of BSCs and MCs for both MVB and SVB showed that the accessions are $\mathrm{C}_{3}-\mathrm{C}_{4}$ intermediate types with a few very close to $\mathrm{C}_{3}$ and $\mathrm{C}_{4}$ types. The outer BSCs were filled with organelles, mainly chloroplasts. The area covered by such BSCs was much higher compared to their proportionate number. Among many species BSCs are larger than MCs; however, no consistent trend with regard to $\mathrm{C}_{4}$ subtype, was established in $P$. milioides (a $\mathrm{C}_{3}-\mathrm{C}_{4}$ intermediate species $)^{36}$. Thus, the genotypes with large parenchymatous BSCs and plenty of chlorophyll therein, belonged to $\mathrm{C}_{3}-\mathrm{C}_{4}$ intermediate types.

The presence of chloroplasts in the BSC and MC is significant in deciding the mode of photosynthesis. Typically, the bundle sheath cells of $\mathrm{C}_{3}$ plants have only a few chloroplasts, and photosynthetic activity is $l_{0} \mathrm{w}^{37,38}$. Presence of chloroplasts and other organelles such as mitochondria and peroxisomes imparting high photosynthetic rate and reduced photorespiration shows the photosynthetic efficiency of the bundle sheath cells. Among genotypes, the area occupied by chloroplasts in the outer BSCs was variable $(<3-100 \%) . \mathrm{C}_{3}$ species, $P$. rivulare, $P$. laxum and $P$. hylaeicum are reported to have 0.7-2 chloroplasts per cell in BSCs in contrast to 10.6 chloroplasts among $\mathrm{C}_{3}-\mathrm{C}_{4}$ species, $P$. milioides, $P$. decipiens and $P$. schenckii ${ }^{28,36,39,40}$. In the present study, the inner bundle sheath was not distinct among 13 genotypes, however, these genotypes possessed distinct outer bundle sheath with variable amounts of chloroplast per cell confirming their $\mathrm{C}_{3}-\mathrm{C}_{4}$ nature and indicating affinity with $P$. prionitis but differing from typical NADP-ME species.

$\mathrm{C}_{4}$ plants are characterized by radially arranged mesophyll cells, mostly single layered, around the $\mathrm{BS}^{41}$, 
whereas many of the genotypes had one to two rhomboid or elliptical cells present between veins with $52.1 \%$ area occupied by chloroplasts. $\mathrm{C}_{4}$ species were distinguished from $\mathrm{C}_{3}$ species by mesophyll to bundle sheath cell number ratio and exposure of the bundle sheath surface to intercellular space without marked distinction between NADP-ME and NAD-ME ${ }^{42}$. Also, the number of inner BSCs together with outer BSCs was more than the number of MC with little intercellular space, which indicated $\mathrm{C}_{3}-\mathrm{C}_{4}$ type.

The stomatal apparatus is responsible for adaptation of genotypes under different moisture and temperature conditions. The shape of stomata regulates the rate of transpiration and indirectly the photosynthetic rate. Thus, the genotypes with sunken stomata will suit tropical rangelands. The bulbiform cells also help as a self defence mechanism against moisture stress by rolling of the leaves. The genotypes with five motor cells in sunken position tend to have better defence against moisture stress.

In the non-Hierarchical Euclidean Cluster Analysis for grouping of genotypes, those with a high number of cells having chloroplast in BSCs of MVB clustered in groups $\mathrm{B}, \mathrm{C}$ and $\mathrm{D}$. The genotypes belonging to group $\mathrm{F}$ possessed minimum (9.6) per cent area occupied by chloroplasts in BSCs of MVB, followed with $21.3 \%$ in group E. Hence, these genotypes, from cluster $\mathrm{F}$ and $\mathrm{E}$, showed similarity with $\mathrm{C}_{3}$ photosynthesis, whereas genotypes in group A with about $50 \%$ area occupied by chloroplasts can be considered as true intermediate types. Cluster B, C and $\mathrm{D}$ genotypes were typical $\mathrm{C}_{4}$ types in terms of chlorophyll pigmentation in BSCs. Interestingly, most of the exotic genotypes from Ethiopia clustered in these groups along with majority of accessions from India, probably because guinea grass is an introduced crop in India and these might have developed from germplasm initially introduced directly or indirectly from Ethiopia.

The photosynthetic pathways reported among different species of the genus together with results of the present study were considered to get an insight into inter-species lineage of this species with other species in the genus. $P$. maximum exhibited high degree of variation for leaf anatomy which was supposed to have originated due to inter-varietal as well as inter-specific crossing. Less pigmentation in BSCs shows its affinity with $\mathrm{C}_{3}$ species $P$. rivulare, $P$. laxum and $P$. hylaeicum, whereas high pigmentation among some genotypes places them close to $\mathrm{C}_{3}-$ $\mathrm{C}_{4}$ species, $P$. milioides, $P$. decipiens and $P$. schenckii. Genotypes with little pigmentation in BSCs and NADP$\mathrm{ME}$ anatomy were closer to non-typical $\mathrm{C}_{4}$ species $P$. prionitis (NADP-ME), which possesses non-chlorophyllous outer bundle sheath of large veins and densely packed BSCs of minor veins having only one sheath ${ }^{5,8,36,43}$. Presence of parenchymatous BS among majority genotypes also shows its lineage with $P$. prionitis and $P$. petersonii. $P$. prionitis and some other species of the
Grandia group of Panicum were proposed as intermediate species than to other non-Kranz Panicum species ${ }^{5}$. The proposed scheme for evolution in Panicum places the NADP-ME group (with functional BSC of large veins developed from the mestome) in a distant line from the NAD-ME with parenchyma sheath group closely resembling the $\mathrm{C}_{3}$ and intermediate species. However, in this study, both genotypes possessing either NAD-ME or NADP-ME anatomy were observed. Hence, there appears a strong likelihood that these genotypes originated from different evolutionary pathways.

The shade conditions under orchards have comparatively low $\mathrm{CO}_{2}$ and many $P$. maximum genotypes perform well under shaded conditions ${ }^{20}$. Hence, such genotypes belong to $\mathrm{C}_{4}$ condition, whereas genotypes showing a drastic loss in biomass under low $\mathrm{CO}_{2}$ might have some $\mathrm{C}_{3}$ lineage. Such small reduction in photosynthesis among $\mathrm{C}_{4}$ species compared to $\mathrm{C}_{3}\left(P\right.$. bisulcatum) and $\mathrm{C}_{3}-\mathrm{C}_{4}$ species ( $P$. milioides) has also been reported earlier ${ }^{44}$.

Thus, the present study establishes that the $P$. maximum genotypes are represented by $\mathrm{C}_{4}$ and $\mathrm{C}_{3}-\mathrm{C}_{4}$ intermediates, of which some are close to $\mathrm{C}_{3}$ and some to $\mathrm{C}_{4}$ and there is a need to look into the possible origin/ evolution of such types. The first possibility is that the genotypes evolved as result of adaptation to moisture, light and $\mathrm{CO}_{2}$ stress conditions. However, this theory does not explain the existence of the continuum of variation at one point of time.

The second possibility is switching of the plants from $\mathrm{C}_{3}$ or $\mathrm{C}_{3}-\mathrm{C}_{4}$ to more $\mathrm{C}_{4}$-like or $\mathrm{C}_{4}$. Although such gene plasticity within an individual was not confirmed in this study, plasticity between $\mathrm{C}_{3}$ and $\mathrm{C}_{4}$ modes has been reported among CAM (crassulacean acid metabolism) plants $^{27,45,46}$. Several genotypes evaluated at the same time under the same environment leaves little chance for individuals to switch over. The third possibility genotypes are a result of crossing between $\mathrm{C}_{3}$ and $\mathrm{C}_{4}$ species and have a polyphyletic origin. This theory holds merit because, first the crossing between $\mathrm{C}_{3}$ and $\mathrm{C}_{4}$ is still the best explained theory regarding the origin of $\mathrm{C}_{3}-\mathrm{C}_{4}$ and the experimentally generated intermediates could also be an excellent source to understand the mechanism ${ }^{47}$. Secondly, interspecies variation for photosynthetic pathway exists in the genus Panicum.

Phylogeny of the species is poorly worked out compared to other species of the genus and most of the studies on phylogeny with $P$. maximum have included only a few genotypes, which certainly does not represent the species with a high degree of variability. In fact, Panicoideae as a whole, and Paniceae in particular, are uniquely variable, comprising many taxa which have $\mathrm{C}_{3}$ as well as $\mathrm{C}_{4}$ subtypes. This variation affords a unique opportunity for phylogenetic study, although it is considered that the PCK $\mathrm{C}_{4}$ subtype arose once within Paniceae ${ }^{48}$. In this context, present set of germplasm, with intra-species diversity for photosynthetic pathways, offers scope for 


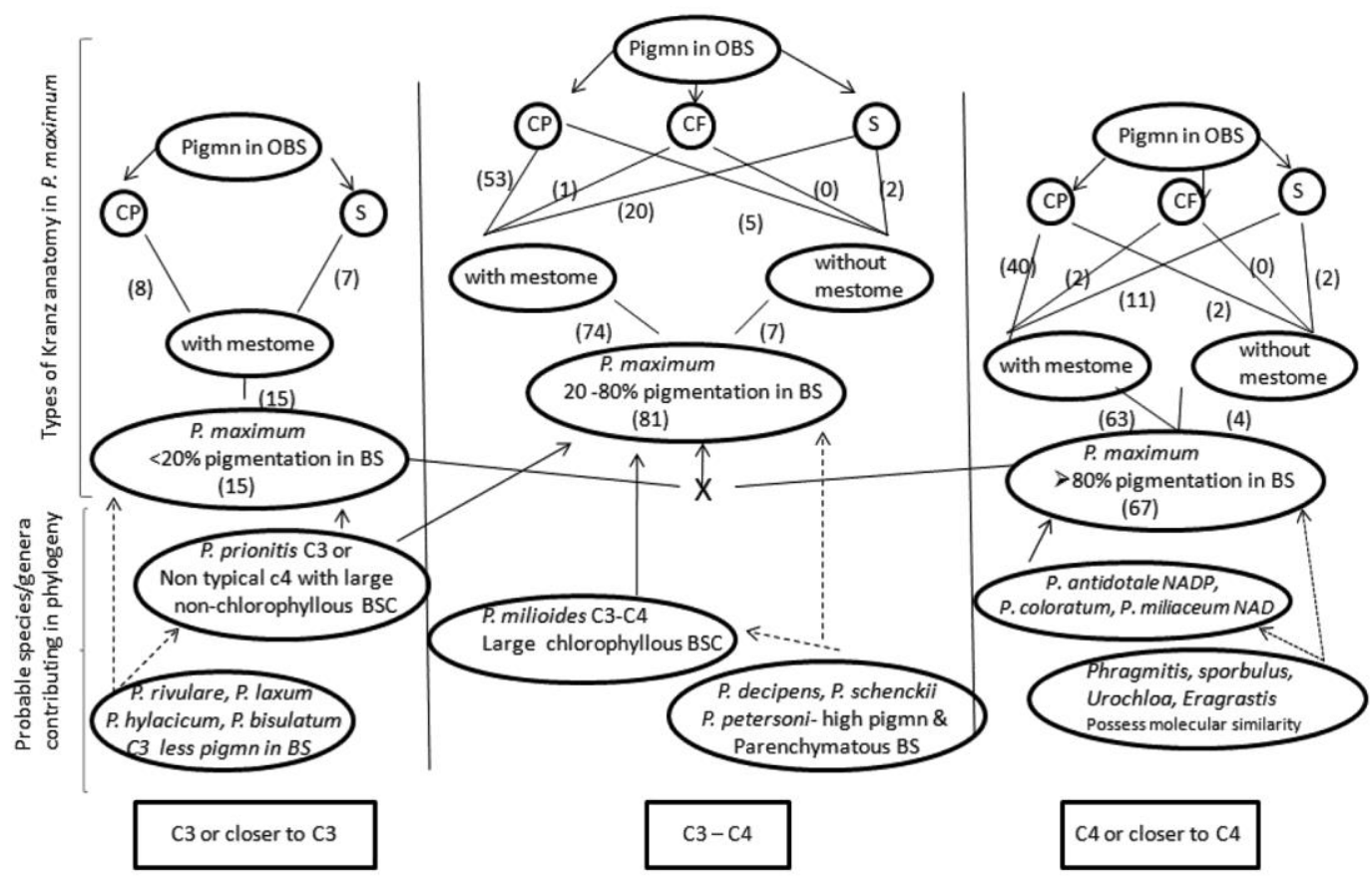

Figure 3. Types of Kranz anatomy in P. maximum and outline of the possible interspecific lineage with other species and genera. Figures in parenthesis represent the number of genotypes belonging to that type. Pigmn, Pigment; BS, Bundle sheath; CP, Centripetal; CF, Centrifugal; S, Scattered; OBS, Outer bundle sheath.

further studies to delineate the origin of $\mathrm{C} 3 / \mathrm{C} 4$ plant types.

P. maximum is represented by polyploid types (mostly tetraploid apomicts) and is considered as autotetraploid, but the present finding establishes the need to examine it carefully for genomic constitution. Cytogenetic studies have suggested the possibility of origin of different cytotypes as two different evolutionary lines ${ }^{49}$. P. miliaceum and $P$. repens have been reported to be of allotetraploid origin $^{2}$. Therefore, in spite of the uncertainty about taxonomic relationships among the species, it is important to establish the possibilities of hybridization among the different photosynthetic types.

Most of the $\mathrm{C}_{4}$ panicoids possess one layer of bundle sheath and are of NADP-ME type, whereas $P$. maximum possesses two layers of BS for most of the genotypes and many reports place the species separate from Paniceae. This type of anatomy, shared with its $\mathrm{C}_{3}$ ancestor, is common in Chlorodoideae ${ }^{50}$. Further, close relationship of chloridoid and panicoid grasses alongwith other $\mathrm{C}_{4}$ grasses suggests the possibility of underlying physiological similarities ${ }^{4}$. Thus, the species shares anatomical similarity with genera such as Phragmitis, Sporobolus, Uniola, Eragrostis of Chloridoideae, leading to the possibility of intergeneric transfer of genes (Figure 3).

PCK subtype of $\mathrm{C}_{4}$ photosynthesis was considered to have one step evolution, whereas NAD-ME and NADPME originated several times ${ }^{51}$. According to this, $P$. maximum having assemblage of all three subtypes must have originated several times through various pathways, i.e. mutation and inter-varietal crossing. It was considered that Panicum is polyphyletic, with lineages derived from multiple ancestors ${ }^{49}$. Based on molecular studies, it was concluded that Setariinae and Digitariinae are paraphyletic with other genera of Paniceae and the monophyletic clad of species that are exclusively $\mathrm{C}_{4}$ PCK, including $P$. maximum $^{52}$. Thus, it leads to the possibility of more than one species and/or genus involved in the evolution of $P$. maximum forming it reticulate (Figure 3).

$P$. maximum due to its molecular as well as morphological dissimilarities has been considered a species separate from the genus Panicum. Also, Panicum subg. Megathyrsus, a monotypic subgenus, including the only species $P$. maximum, was supposed to be better placed in Urochloa $^{31,51}$. Later in a phylogenetic study, Megathyrasus maximus did not appear in the clad of other species of Panicinae and appeared with Zuleagaea bulbosa and Melinis in the clad Melinidinae ${ }^{53}$. Molecular studies revealed that within the subtribe Panicinae, only the NADME type of $\mathrm{C}_{4}$ photosynthesis was present, whereas $M$.

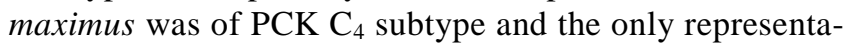
tive of the Melinidinae clade in the DNA-barcoding anal$\mathrm{ysis}^{54}$, the sister clade to the Panicinae clade. M. maximus formed groups with typical $\mathrm{C}_{4}$ Zea mays, Sorghum officinarum and Sorghum bicolour and did not join the clad of other Panicum species. The association of $P$. maximum with Urochloa/Erichloa in the PCK clad and the position of $P$. laxum in the same general clad as Arthropogon lanceolatus are noteworthy. The correlated morphophysiological synapomorphies of $P$. maximum and $P$. laxum 
with other members of their respective clades suggest that Panicum has at least some degree of polyphyly ${ }^{51,52}$.

Thus, evolution of the species appears to be polyphyletic (Figure 3) although Panicum was considered as polyphyletic but the subgenus Panicum as monophyletic ${ }^{31}$. Additionally, $\mathrm{C}_{4}$ and $\mathrm{C}_{3}-\mathrm{C}_{4}$ intermediate modes of photosynthesis present in $P$. maximum must have provided an opportunity of natural selection of climate-resilient genotypes over the years. Operation of a mixed mode of $\mathrm{C}_{4}$ photosynthesis is considered to confer higher ecological robustness ${ }^{55}$. In the present scenario of changing climate, the guinea grass genotypes with observed intra-species continuous variation have ample opportunity for adaptation. Further, this can prove to be a valuable genetic resource for understanding evolution of photosynthetic pathways.

1. Akhani, H., Ghasemkhani, M., Chuong, S. D. X. and Edwards, G. E., Occurrence and forms of Kranz anatomy in photosynthetic organs and characterization of NAD-ME subtype $\mathrm{C}_{4}$ photosynthesis in Blepharis ciliaris (L.) B. L. Burtt (Acanthaceae). J. Exp. Bot., 2008, 59, 1755-1765.

2. Hunt, H. V., Badakshi, F., Romanova, O., Howe, C. J., Jones, M K. and Heslop-Harrison, J. S. P., Reticulate evolution in Panicum (Poaceae): the origin of tetraploid broomcorn millet, P. miliaceum. J. Exp. Bot., 2014, 65, 3165-3175.

3. Zimmermann, T., Bocksberger, G., Brüggemann, W. and Berberich, T., Phylogenetic relationship and molecular taxonomy of African grasses of the genus Panicum inferred from four chloroplast DNA-barcodes and nuclear gene sequences. J. Plant Res., 2013 , 126, 363-371

4. Kellogg, E. A., Evolotionary history of the grasses. Plant Physiol., 2001, 125, 1198-1205.

5. Brown, W. V., The Kranz syndrome and its types in grass systematics. Mem. Torrey Bot. Club, 1977, 23, 1-97.

6. Brown, R. H. and Smith, B. N., The genus Dichanthelium (Gramineae). Bull. Torrey Bot. Club, 1975, 102, 10-13.

7. Ku, M. S. B. and Edwards, G. E., Photosynthetic efficiency of Panicum hians and Panicum milioides in relation to $\mathrm{C}_{3}$ and $\mathrm{C}_{4}$ plants. Plant Cell Physiol., 1978, 19, 665-675.

8. Morgan, J. A. and Brown, R. H., Photosynthesis in grass species differing in carbon dioxide fixation pathways. II. A search for species with intermediate gas exchange and anatomical characteristics. Plant Physiol., 1979, 64, 257-262.

9. Brown, R. H., Bouton, J. H., Evans, P. T., Malter, H. E. and Rigsby, L. L. Photosynthesis, morphology, leaf anatomy, and cytogenetics of hybrids between $\mathrm{C}_{3}$ and $\mathrm{C}_{3} / \mathrm{C}_{4}$ Panicum species. Plant Physiol., 1985, 77, 653-658.

10. Hattersley, P. W., Wong, S. C., Perry, S. and Roksandic, Z., Comparative ultrastructure and gas exchange characteristics of the $\mathrm{C}_{3}-\mathrm{C}_{4}$ intermediate Neurachne minor S. T. Blake (Poaceae). Plant, Cell Environ., 1986, 9, 217-233.

11. Zuloaga, F. O., Morrone, O., Vega, A. S. and Giussani, L. M., Revisión y análisis cladístico de Steinchisma (Poaceae: Panicoideae: Paniceae). Ann. Mol. Botan. Gard., 1998, 85, 631656.

12. Downton, W. J. S., The occurrence of $\mathrm{C}_{4}$ photosynthesis among the plants. Photosynthetica, 1975, 9, 96-105.

13. Hatch, M. D., Kagawa, T. and Craig, S., Subdivision of $\mathrm{C}_{4}$ pathway species based on differing $\mathrm{C}_{4}$ acid decarboxylating systems and ultrastructural features. Aust. J. Plant Physiol., 1975, 2, 111128
14. Bogdan, A. B., Trop. Pastures Fodder Plants, Longman, London, NY, 1977.

15. Sukhchain and Sidhu, B. S., Correlation and path coefficients analysis for reproductive traits in guinea grass. Euphytica, 1992, 60, 57-60.

16. Malaviya, D. R., Distribution of morphological diversity among germplasm lines of Panicum maximum. Indian J. Plant Genet. Resour., 1996, 9, 193-196.

17. Malaviya, D. R., Components of green fodder yield in Panicum maximum Jacq. Indian J. Genet. Plant Breed., 1995, 59, 83-86.

18. Malaviya, D. R., Evaluation of Panicum maximum lines for sustained productivity. Range Manage. Agrofor., 1998, 19, 126-132.

19. Malaviya, D. R., Breeding for quality characters in Panicum maximum Jacq. Indian J. Genet. Plant Breed., 2001, 61, 169.

20. Malaviya, D. R., Kaushal, P. and Kumar, B., Differential response of guinea grass (Panicum maximum) morphotypes to shade under rainfed condition. Range Manage. Agrofor., 2006, 27, 70-76.

21. Ueno, O., Occurrence of distinctive cells in leaves of $\mathrm{C}_{4}$ species in Arthraxon and Microstegium (Andropogoneae-Poaceae) and the structural and immunocytochemical characterization of these cells. Int. J. Plant Sci., 1995, 156, 270-289.

22. Spark, D. N., Euclidean cluster analysis. Algorithm As 58. Appl. Stat., 1973, 22, 126-130.

23. Rohlf, F. J., NTSYS-pc: Numerical Taxonomy and Multivariate Analysis System. Version 2.02j, Exeter Biological Software, Biostatistics Inc., Setauket, NY, USA, 1998.

24. Jain, A., Roy, A. K., Kaushal, P., Malaviya, D. R. and Zadoo, S., $\mathrm{N}$., Isozyme banding pattern and estimation of genetic diversity among guinea grass germplasm. Genet. Resour. Crop Evol., 2005 , 53, 339-347.

25. Kaushal, P., Malaviya, D. R., Roy, A. K., Pathak, S., Agrawal, A., Khare, A. and Siddiqui, S. A., Reproductive pathways of seed development in apomictic guinea grass (Panicum maximum Jacq.) reveal uncoupling of apomixis components. Euphytica, 2008, 164, $81-92$.

26. Kaushal, P., Agarwal, A., Malaviya, D. R., Siddique, S. A. and Roy, A. K., Ploidy manipulation in guinea grass (Panicum maximum Jacq., Poaceae) utilizing a hybridization-supplemented apomixis-component partitioning approach (HAPA). Plant Breed., 2009, 128, 295-303.

27. Ehleringer, J. R. and Monson, R. K., Evolutionary and ecological aspects of photosynthetic pathway variation. Annu. Rev. Ecol. System., 1993, 24, 411-439.

28. Hatch, M. D., C 4 photosynthesis: a unique blend of modified biochemistry, anatomy and ultra-structure. Biochim. Biophys. Acta, 1987, 895, 81-106.

29. Zuloaga, F. O., Systematics of new world species of Panicum (Poaceae: Paniceae). In Grass Systematics and Evolution (eds Soderstrom, T. R. et al.), Smithsonian Institution Press, Washington, DC, USA, 1987, pp. 287-306

30. Brown, R. H. and Hattersley, P. W., Leaf anatomy of $\mathrm{C}_{3}-\mathrm{C}_{4}$ species as related to evolution of $\mathrm{C}_{4}$ photosynthesis. Plant Physiol., 1989, 91, 1543-1550.

31. Aliscioni, S. S., Giussani, L. M., Zuloaga, F. O. and Kellogg, E. A., A molecular phylogeny of Panicum (Poaceae: Paniceae): tests of monophyly and phylogenetic placement within the Panicoideae. Am. J. Bot., 2003, 90, 796-821.

32. Ohsugi, R. and Murata, T., $\mathrm{C}_{4}$ photosynthetic characteristics of Panicum species in the dichotomiflora group (Gramineae). Jpn. Agric. Res. Q., 1985, 19, 125-131.

33. Ueno, O., Kawano, Y., Wakayama, M. and Takeda, T., Leaf vascular systems in $\mathrm{C}_{3}$ and $\mathrm{C}_{4}$ grasses: a two-dimensional analysis. Ann. Bot., 2006, 97, 611-621.

34. Dengler, N. G., Dengler, R. E., Donnelly, P. M. and Hattersley, P. W., Quantitative leaf anatomy of $\mathrm{C}_{3}$ and $\mathrm{C}_{4}$ grasses (Poaceae): bundle sheath and mesophyll surface area relationships. Ann. Bot., 1994, 73, 241-255. 


\section{RESEARCH ARTICLES}

35. Kawamitsu, Y., Hakoyama, S., Agata, W. and Takeda, T., Leaf interveinal distances corresponding to anatomical types in grasses. Plant Cell Physiol., 1985, 26, 589-593.

36. Brown, R. H., Bouton, J. H., Rigsby, L. and Rigler, M., Photosynthesis of grass species differing in carbon dioxide fixation pathways. VIII. Ultrastructural characteristics of Panicum species in the Laxa group. Plant Physiol., 1983, 71, 425-431.

37. Gowik, U. and Westhoff, P., The path from $\mathrm{C}_{3}$ to $\mathrm{C}_{4}$ photosynthesis. Plant Physiol., 2011, 155, 56-63.

38. Lundgren, M. R., Osborne, C. P. and Christin, P., Deconstructing Kranz anatomy to understand $\mathrm{C}_{4}$ evolution. J. Exp. Bot., 2014, 65 , 3357-3369.

39. Prendergast, H. V. D., Hattersley, P. W. and Stone, N. E., New structural/biochemical associations in leaf blades of $\mathrm{C}_{4}$ grasses (Poaceae). Aust. J. Plant Physiol., 1987, 14, 403-420.

40. Yoshimura, Y., Kubota, F. and Ueno, O., Structural and biochemical bases of photorespiration in $\mathrm{C}_{4}$ plants: quantification of organelles and glycine decarboxylase. Planta, 2004, 220, 307-317.

41. Hattersley, P. W. and Watson, L., Anatomical parameters for predicting photosynthetic pathways of grass leaves: the 'maximum lateral cell count' and the 'maximum cell distant count'. Phytomorphology, 1975, 25, 325-333.

42. Muhaidat, R., Sage, R. F. and Dengler, N. G., Diversity of Kranz anatomy and biochemistry in $\mathrm{C}_{4}$ eudicots. Am. J. Bot., 2007, 94, $362-381$.

43. Morgan, J. A., Brown, R. H. and Reger, B. J., Photosynthesis of grass species differing in carbon dioxide fixation pathways. III. Oxygen response and enzyme activities of species in the Laxa group of Panicum. Plant Physiol., 1980, 65, 156-159.

44. Pinto, H., Sharwood, R. E., Tissue, D. T. and Ghannoum, O., Photosynthesis of $\mathrm{C}_{3}, \mathrm{C}_{3}-\mathrm{C}_{4}$, and $\mathrm{C}_{4}$ grasses at glacial $\mathrm{CO}_{2}$. J. Exp. Bot., 2014, 65, 3669-3681.

45. Ueno, O., Environmental regulation of $\mathrm{C}_{3}$ and $\mathrm{C}_{4}$ differentiation in the amphibious sedge Eleocharis vivipara. Plant Physiol., 2001, 127, 1524-1532.

46. Ueno, O., Environmental regulation of photosynthetic metabolism in the amphibious sedge Eleocharis baldwinii and comparisons with related species. Plant Cell Environ., 2004, 27, 627-639.
47. Kadereit, G., Bohley, K., Lauterbach, M., Tefarikis, D. T. and Kadereit, D. W., $\mathrm{C}_{3}-\mathrm{C}_{4}$ intermediates may be of hybrid origin - a reminder. New Phytol., 2017, 215, 70-76.

48. Duvall, M. R., Noll, J. D. and Minn, A. H., Phylogenetics of Paniceae (Poaceae). Am. J. Bot., 2001, 88, 1988-1992.

49. Jain, A., Zadoo, S. N., Roy, A. K., Kaushal, P. and Malaviya, D. R., Meiotic system and probable basic chromosome number of Panicum maximum Jacq. accessions. Cytologia, 2003, 68, 7-13.

50. Sinha, N. R. and Kellogg, E. A., Parallelism and diversity in multiple orgins of $\mathrm{C}_{4}$ photosynthesis in grasses. Am. J. Bot., 1996, 83, 1458-1470.

51. Giussani, L. M., Cota-Sa, J. H., Nchez, Zuloaga, F. O. and Kellogg, E. A., A molecular phylogeny of the grass subfamily Panicoideae (poaceae) shows multiple origins of $\mathrm{C}_{4}$ photosynthesis. Am. J. Bot., 2001, 88, 1993-2012.

52. Gómez-Martínez, R. and Culham, A., Phylogeny of the subfamily Panicoideae with emphasis on the tribe Paniceae: evidence from the trnL-F cpDNA region. In Grasses: Systematics and Evolution (Jacobs, S. W. L. and Everett, J.), CSIRO Publishing, Australia, 2000, pp. 136-140.

53. Zuloaga, F. O., Salomón, L. and Scataglini M. A., Phylogeny of sections Clavelligerae and Pectinatae of Panicum (Poaceae, Panicoideae, Paniceae): establishment of the new subtribe Dichantheliinae and the genus Adenochloa. Plant Syst. Evol., 2015, 301, 1693-1711.

54. Salariato, D. L., Zuloaga, F. O., Giussani, L. M. and Morrone, O., Molecular phylogeny of the subtribe Melinidinae (Poaceae: Panicoideae: Paniceae) and evolutionary trends in the homogenization of inflorescences. Mol. Phylogeny Evol., 2010, 56, 355-369.

55. Wang, Y., Bräutigam, A., Weber, A. P. M. and Zhu, X., Three distinct biochemical subtypes of $\mathrm{C}_{4}$ photosynthesis? A modelling analysis. J. Exp. Bot., 2014, 65, 3567-3578.

Received 18 March 2018; revised accepted 3 June 2020

doi: 10.18520/cs/v119/i5/808-816 